\title{
INVESTIGATION OF THE GENETIC CORRELATION BETWEEN MILK AND FERTILITY TRAITS OF FIRST CALVING COWS OF SIMMENTAL BREED **
}

\section{Pantelicí ${ }^{1 *}$, M. M. Petrović ${ }^{1}$, S. Aleksićc ${ }^{1}$ Lj. Sretenović ${ }^{1,}$ D. Ostojić- Andrić $^{1}$, Ž. Novaković ${ }^{1}$}

${ }^{1}$ Institute for Animal Husbandry, Belgrade-Zemun, 11080 Zemun

* Corresponding author: Vlada Pantelić, e-mail: vladapantelic.izs@gmail.com

**Original scientific paper - Originalni naučni rad

Research was financed by the Ministry of Science of Republic of Serbia within project TR 20042/08 - Rad je finansiran od strane Ministarstva za nauku Republike Srbije u okviru projekta TR 20042/08

Abstract: Investigation of the production capacity of cattle for the purpose of increase of milk and milk fat production, as well as number of calves, greatly depends on phenotypic and genetic variability, heritability and correlation between desired traits, and on production level in the population. This research included 3.461 first calving cows of Simmental breed under control and reared on farms of individual agricultural producers on the territory of Republic of Serbia. Genetic correlations were calculated using equation of mixed model which included the effect of bull-sire, breeding region, year and season of calving: $\mathrm{Y}_{\mathrm{ijklm}}=\mu+\mathrm{B}_{\mathrm{i}}+\mathrm{R}_{\mathrm{j}}+\mathrm{G}_{\mathrm{k}}+\mathrm{S}_{1}+\mathrm{e}_{\mathrm{ijklm}}$.

Coefficients of genetic correlation between service period and milk traits were following: duration of lactation 0,239 , milk yield 0,089 , percentage of milk fat 0,095 , quantity of milk fat 0,105 and yield of $4 \%$ FCM 0,099 . Correlation between service period and age at calving was 0,535. Genetic correlation between age at calving and milk traits was following: duration of lactation 0,245 , production of milk 0,003 , percentage of milk fat 0,531 , quantity of milk fat 0,082 and production of $4 \% \mathrm{FCM} 0,050$.

Key words: genetic correlations, milk yield, fertility, Simmental breed. 


\section{Introduction and literature review}

Genetic correlations are very important in direct or indirect selection where changes in one trait are induced by selection on another trait between which there is genetic correlation. Chaunan and Hayes (1991) established the medium to highly positive genetic correlation between production of milk and milk fat $0,45 \pm 0,053$, between content and yield of milk fat $0,56 \pm 0,045$, and between milk yield and milk fat content $0,49 \pm 0,050$.

Campos et al. (1994), in their investigation of genetic parameters of milk and reproductive traits of cows Holstein breed, established the genetic correlation between yield of milk and milk fat of 0,743 , between yield of milk and milk fat content of 0,235 , milk yield and duration of service period of 0,159 , and milk yield and calving interval of 0,170 .

Positive values of genetic correlation between milk traits, with the exception of correlation between milk yield and milk fat content, were also concluded by Marković (1999). Parameters of genetic correlation varied from -$-0,78$ (milk yield and milk fat content) to 0,95 (yield of milk and $4 \% \mathrm{FCM}$ ).

Costa et al. (2000) in their research related to genetic analysis of Holstein-Friesian population in USA and Brasil established value of the coefficient of genetic correlation between production of milk and milk fat of 0,79 in Brasil and 0,62 in USA.

Gaydarska et al. (2001) established strong and positive genetic correlation between production of milk and milk fat of 0,953 . Correlation between milk yield and percentage of milk fat was negative $-0,155$. Slightly positive genetic correlation of 0,171 was established between production and percentage of milk fat.

Oseni et al. (2004), in their investigation of genetic parameters relating to service period and duration of pregnancy stated data on correlation between milk production and duration of service period of 0,12 do 0,6 .

\section{Material and methods}

This research included 3.461 first calving cows of Simmental breed, with lactations completed within one year. All first calving cows were reared on farms of individual agricultural producers on the territory of Republic of Serbia. In this paper, genetic correlation between following milk and reproductive traits were investigated:

- duration of lactation (days)-DL

- milk yield in standard lactation ( $\mathrm{kg}$ )-MY

- milk fat content in standard lactation (\%)-MFC 
- milk fat yield in standard lactation (kg)-MFY

- yield of 4\% FCM in standard lactation (kg)-4\%MKM

- age at first calving (days)-AC

- duration of service period (days)-DSP

Results of the investigation of genetic correlations were obtained using mixed model:

$$
\mathrm{Y}_{\mathrm{ijklm}}=\mu+\mathrm{B}_{\mathrm{i}}+\mathrm{R}_{\mathrm{j}}+\mathrm{G}_{\mathrm{k}}+\mathrm{S}_{1}+\mathrm{e}_{\mathrm{ijklm}}
$$

$\mathrm{Y}_{\mathrm{ijklm}}=$ expression of a trait of $m$ cow, daughter of $i$ bull sire, which produced in $j$ region, and calved in $k$ year and $l$ season

$$
\begin{array}{ll}
\mu & =\text { general average } \\
\mathrm{B}_{\mathrm{i}} & =\text { random effect of } i \text { bull sire } \\
\mathrm{R}_{\mathrm{j}} & =\text { fixed effect of } j \text { region } \\
\mathrm{G}_{\mathrm{k}} & =\text { fixed effect of } k \text { calving year } \\
\mathrm{S}_{1} & =\text { fixed effect of } l \text { calving season } \\
\mathrm{e}_{\mathrm{ijklm}} & =\text { random error }
\end{array}
$$

For analyzed milk and reproduction traits basic variation-statistical parameters were calculated: arithmetic mean $(\bar{X})$, standard deviation (SD), variation coefficient $(\mathrm{CV})$, standard error of the average $(\mathrm{S} \bar{X})$, and variation interval (Min-Max).

\section{Results and discussion}

Increase of production and quality of milk, as well as of fertility intensity, are main prerequisites of modern cattle production. Based on obtained results presented in table 1 it can be concluded that average duration of lactation was 311,72 days, milk yield $3.885,96 \mathrm{~kg}$, content of milk fat $3.88 \%$, yield of milk fat $150,63 \mathrm{~kg}$ and yield of $4 \% \mathrm{FCM} 3.813,84 \mathrm{~kg}$.

Tabela 1. Srednje vrednosti i varijabilnost osobina mlečnosti u standardnoj laktaciji Table 2. Mean values and variability of milk traits in standard lactation

\begin{tabular}{|l|r|r|r|r|r|r|}
\hline \multicolumn{1}{|c|}{ Osobina/Trait } & \multicolumn{1}{c|}{$\bar{X}$} & \multicolumn{1}{c|}{ SD } & \multicolumn{1}{c|}{ CV } & \multicolumn{1}{c|}{$\mathbf{S}_{X}$} & \multicolumn{1}{c|}{ Min } & \multicolumn{1}{c|}{ Max } \\
\hline TL, dana/DL, days & 311.72 & 28.50 & 9.14 & 0.48 & 241 & 586 \\
\hline PM, kg/MY, kg & 3885.96 & 609.63 & 15.69 & 10.36 & 1586 & 7686 \\
\hline SMM, \%/MFC, \% & 3.88 & 0.17 & 4.44 & 0.00 & 2.85 & 4.87 \\
\hline PMM, kg/MFY, kg & 150.63 & 24.37 & 16.18 & 0.41 & 56.80 & 316.86 \\
\hline $\begin{array}{l}\text { 4\%MKM, kg/ } \\
\text { 4\%FCM, kg }\end{array}$ & 3813.84 & 604.37 & 17.46 & 9.79 & 1492 & 7376 \\
\hline
\end{tabular}


Mean values and variability of investigated fertility traits are presented in table 2. Average duration of service period was 110,79 days, with standard deviation of 53,81 days. Variability of service period was rather high and varied in the interval from minimum 40 to maximum 361 days. Average age of cows at first calving was 778,73 days with coefficient of variation of 11,13 .

Tabela 2. Srednje vrednosti i varijabilnost osobina plodnosti

Table 2. Mean values and variability of fertility traits

\begin{tabular}{|c|c|c|c|c|c|c|}
\hline Osobina/Trait & $\bar{X}$ & SD & CV & $\mathbf{S} \bar{X}$ & Min & Max \\
\hline $\begin{array}{c}\text { TSP, dana/ } \\
\text { DSP, days }\end{array}$ & 110.79 & 53.81 & 48.57 & 0.91 & 40 & 361 \\
\hline $\begin{array}{c}\text { UPT,dana/ AC, } \\
\text { days }\end{array}$ & 778.73 & 86.66 & 11.13 & 1.47 & 620 & 1079 \\
\hline
\end{tabular}

Genetic correlations can be positive, when change of additive gene effect in one trait induces change of additive gene effect, in the same direction, of another trait. Negative genetic correlation designates changes of additive gene effect of two traits but in the opposite directions. Increase of additive effect in one trait is followed by decrease/diminishing of the stated effect in other trait, and vice versa.

Genetic correlation between milk and fertility traits and their errors are presented in table 3 . Obtained results of genetic correlations between production of milk and milk fat $(0,989)$, and between yield of milk and 4\%FCM $(0,996)$ indicate the presence of strong and complete correlation between these two traits. Correlation between production of milk and content of milk fat was negative, as expected, $-0,125$.

Genetic correlations of milk traits and duration of service periods and age at first calving were weak and slightly positive, respectively. Correlation coefficients between service period and milk traits were: duration of lactation 0,239 , milk yield 0,089 , percentage of milk fat 0,095 , quantity of milk fat 0,105 , yield of $4 \% \mathrm{FCM} 0,099$. Correlation between service period and age at calving was 0,535 .

Genetic correlation of age at calving and milk traits had the following values: duration of lactation 0,245 , production of milk 0,003 , percentage of milk fat 0,531 , quantity of milk fat 0,082 and production of $4 \% \mathrm{FCM} 0,050$. So, it can be concluded that milk and fertility traits were in positive genetic correlation, and their coefficients varied from very weak to medium strong.

Positive values of coefficients of genetic correlations between milk yield and service period were also established by Campos et al. (1994), Stojić (1996), Petrović et al. (1998) and Oseni et al. (2004). Positive correlation between milk yield and age at calving is stated by Petrović et al. (1998), who 
established also positive correlation between duration of service period and age at calving, on one side, and production of milk fat, on the other. Negative correlation coefficients of production of milk and milk fat in standard lactation and age at calving is stated by Moore et al. (1991) and Stojić (1996).

Tabela 3. Koeficijenti genetskih korelacija $\left(r_{g}\right)$ i njihove greške $\left(\mathrm{Sr}_{\mathrm{g}}\right)$ izmedju osobina mlečnosti i plodnosti u standardnoj laktaciji

Table 3. Coefficients of genetic correlations $\left(r_{g}\right)$ and their errors $\left(\operatorname{Sr}_{g}\right)$ between milk and fertility traits in standard lactation

\begin{tabular}{|c|c|c|}
\hline Osobine/Trait & $\mathbf{r}_{\mathrm{g}}$ & $\mathbf{S r}_{\mathrm{g}}$ \\
\hline \multicolumn{3}{|c|}{ TL, dana/DL, days } \\
\hline $\mathrm{PM}, \mathrm{kg} / \mathrm{MY}, \mathrm{kg}$ & -0.121 & 0.244 \\
\hline SMM, \%/MFC, \% & 0.099 & 0.307 \\
\hline PMM, kg/MFY, kg & -0.1 & 0.246 \\
\hline $4 \% \mathrm{MKM}, \mathrm{kg} / 4 \%$ FCM, $\mathrm{kg}$ & -0.109 & 0.245 \\
\hline TSP, dana/DSP, days & 0.239 & 0.281 \\
\hline UPT, dana/AC, days & 0.245 & 0.302 \\
\hline \multicolumn{3}{|c|}{$\mathrm{PM}, \mathrm{kg} / \mathrm{MY}, \mathrm{kg}$} \\
\hline SMM, \%/MFC, \% & -0.125 & 0.237 \\
\hline PMM, kg/MFY, kg & 0.989 & 0.005 \\
\hline $4 \% \mathrm{MKM}, \mathrm{kg} / 4 \%$ FCM, kg & 0.996 & 0.002 \\
\hline TSP, dana/DSP, days & 0.089 & 0.232 \\
\hline UPT, dana/AC, days & 0.003 & 0.239 \\
\hline \multicolumn{3}{|c|}{ SMM, \%/MFC, \% } \\
\hline PMM, kg/MFY, kg & 0.022 & 0.24 \\
\hline $4 \% \mathrm{MKM}, \mathrm{kg} / 4 \%$ FCM, kg & -0.038 & 0.239 \\
\hline TSP, dana/DSP, days & 0.095 & 0.292 \\
\hline UPT, dana/AC, days & 0.531 & 0.267 \\
\hline \multicolumn{3}{|c|}{ PMM, kg/MFY, kg } \\
\hline $4 \% \mathrm{MKM}, \mathrm{kg} / 4 \%$ FCM, kg & 0.998 & 0.001 \\
\hline TSP, dana/DSP, days & 0.105 & 0.232 \\
\hline UPT, dana/AC, days & 0.082 & 0.24 \\
\hline \multicolumn{3}{|c|}{ 4\%MKM, kg/4\% FCM, kg } \\
\hline TSP, dana/DSP, days & 0.099 & 0.232 \\
\hline UPT, dana/AC, days & 0.050 & 0.239 \\
\hline \multicolumn{3}{|c|}{ TSP, dana/DSP, days } \\
\hline UPT, dana/AC, days & 0.535 & 0.252 \\
\hline
\end{tabular}


Negative correlation between production of milk and percentage of milk fat, and positive between milk yield and quantity of milk fat and $4 \% \mathrm{FCM}$ were established in researches of numerous authors: Chaunan and Hayes (1991), Campos et al. (1994), Marković M. (1999), Costa et al. (2000) and Gaydarska et al. (2001).

Main goal of breeding-selection activities is to create new generations which will exceed in regard to their production results preceding generations and express higher production effects in production of milk and meat. Therefore, in selection activity, the knowledge of breeding value of parent couples, as well as degree of heredity to progeny and correlation of major traits is necessary. Evaluation of genetic correlations for milk yield, yield and content of milk fat had very high mutual dependence which indicated that for the selection and breeding purposes data obtained in the first lactation can be used.

\section{Conclusion}

Economical efficiency and success in livestock production most often depend on numerous properties. Therefore it is necessary to carry out so called simultaneous selection on several traits. Simultaneous selection on more traits depends on genetic correlations which represent presence of correlation between additive gene effects which influence/induce the expression of two traits.

Genetic correlations are very significant in direct or indirect selection where changes in one trait are induced through selection on other trait between which there is genetic correlation. Genetic correlations can be determined in all cases where heritability coefficient can be calculated.

Values of genetic correlations between production and reproduction traits have great significance in selection of cows, since they provide possibility for selection of heads on more traits at the same time.

This is becoming especially important in relation to application of modern methods of mathematical statistics in evaluation of additive genetic value of bulls and cows. Also, early selection of parents based on first lactation is possible, which considerably shortens the period of introduction of bulls to breeding. 


\title{
Ispitivanje genetske povezanosti osobina mlečnosti i plodnosti prvotelki simentalske rase
}

\author{
V. Pantelić, M. M. Petrović, S. Aleksić, Lj. Sretenović, D. Ostojić-Andrić, \\ Ž. Novaković
}

\section{Rezime}

Ispitivanje proizvodnih kapaciteta goveda u cilju povećanja proizvodnje mleka, mlečne masti i broja teladi, u velikoj meri zavisi od fenotipske i genetske varijabilnosti, heritabiliteta i povezanosti poželjnih osobina, kao i nivoa proizvodnje u populaciji. Ovim istraživanjem je obuhvaćena 3.461 kontrolisana prvotelka simentalske rase na imanjima individualnih poljoprivrednih proizvođača na području Republike Srbije. Genetske korelacije izračunate su jednačinom mešovitog modela koja uključuje uticaj bika-oca, odgajivačkog područja odnosno regiona, godine i sezone teljenja: $\mathrm{Y}_{\mathrm{ijk} k \mathrm{~m}}=\mu+$ $\mathrm{B}_{\mathrm{i}}+\mathrm{R}_{\mathrm{j}}+\mathrm{G}_{\mathrm{k}}+\mathrm{S}_{1}+\mathrm{e}_{\mathrm{ijk} l \mathrm{~m}}$.

Koeficijenti genetske povezanosti između servis perioda i osobina mlečnosti su sledeći: trajanje laktacije 0,239 , prinos mleka 0,089 , procenat mlečne masti 0,095 , količina mlečne masti 0,105 i prinos $4 \%$ MKM 0,099 . Povezanost servis perioda i uzrasta pri telenju iznosila je 0,535. Genetska povezanost uzrasta pri telenju sa osobinama mlečnosti iznosila je: trajanje laktacije 0,245 , proizvodnja mleka 0,003 , procenat mlečne masti 0,531 , količina mlečne masti 0,082 i proizvodnja 4\%MKM 0,050 .

Ključne reči: genetske korelacije, mlečnost, plodnost, simentalska rasa.

\section{Literature}

CAMPOS, M.S., WILCOX, C.J., BECERRIL, C.M., DIZ, A. (1994): Genetic Parameters for Yield and Reproductive Traits of Holstein and Jersey Cattle in Florida. Journal of Dairy Science 77, 867-873. 
CHAUNAN, V.P.S., HAYES, J.F. (1991): Genetic Parameters for First Lactation Production and Composition Traits for Holsteins Using Multivariate Restricted Maximum Likelihood. Journal of Dairy Science 74 (2), 603-610. COSTA, N.R., BLAKE, W.R., POLLAK, J.E., OLTENACU, A.P., QUAS, L.R., SEARLE, R.S. (2000): Genetic Analysis of Holstein Cattle Populations in Brasil and The United States. Journal of Dairy Science 83 (12), 2963-2974.

GAYDARSKA, V., KRUSTEV, K., SIMEONOVA, S., IVANOV, M. (2001): Influence of environmental and genetic factors on the milk yield and phenotypic and genotypic parameters of milk production in Black-and-White dairy cows in Bulgaria. Biotechnology in Animal Husbandry 17 (1-2), p. 11-15.

MARKOVIĆ, M (1999): Mješoviti modeli-BLUP i ANIMAL model u procjeni oplemenjivačke vrednosti bikova holštajn-frizijske rase. Doktorska disertacija. Poljoprivredni fakultet, Novi Sad.

OSENI, S., TSURUTA, S., MISZTAL, I., REKAYA, R. (2004): Genetic parameters for days open and pregnancy rates in US Holsteins using different editing criteria. Journal of Dairy Science 87 (12), 4327-4333.

PETROVIĆ, M.M, LAZAREVIĆ, R., LAZAREVIĆ, LJ., MIŠČEVIĆ, B., ALEKSIĆ, S., NIKITOVIĆ, N. (1998): Naslednost i povezanost reproduktivnih osobina i mlečnosti crno belih goveda. Biotehnologija u stočarstvu, p. 15-20.

STOJIĆ, P. (1996): Faktori korekcije osobina mlečnosti i njihov doprinos oceni priplodne vrednosti bikova i krava. Doktorska disertacija. Poljoprivredni fakultet, Beograd. 